NBER WORKING PAPER SERIES

COVERED FARM MORTGAGE BONDS IN THE LATE NINETEENTH CENTURY U.S.

Kenneth A. Snowden

Working Paper 16242

http://www.nber.org/papers/w16242

\author{
NATIONAL BUREAU OF ECONOMIC RESEARCH \\ 1050 Massachusetts Avenue \\ Cambridge, MA 02138 \\ July 2010
}

This paper has benefited from the comments of Walid BuSaba, Charles Courtemanche, John Neufeld, Dan Rosenbaum, Chris Ruhm, Chris Swann, Insan Tunali, two anonymous referees and participants of seminars at UNC Greensboro, Rutgers and the University of Western Ontario. Nidal Abu Saba assembled the Watkins loan sample while Debra Ritch and Michael Cofer provided invaluable research assistance in coding Watkins's mortgage ledgers. The material is based upon work supported by the National Science Foundation Grant No. SES-9122566. The views expressed herein are those of the author and do not necessarily reflect the views of the National Bureau of Economic Research.

NBER working papers are circulated for discussion and comment purposes. They have not been peerreviewed or been subject to the review by the NBER Board of Directors that accompanies official NBER publications.

(C) 2010 by Kenneth A. Snowden. All rights reserved. Short sections of text, not to exceed two paragraphs, may be quoted without explicit permission provided that full credit, including $\odot$ notice, is given to the source. 
Covered Farm Mortgage Bonds in the Late Nineteenth Century U.S.

Kenneth A. Snowden

NBER Working Paper No. 16242

July 2010

JEL No. G28,G29,N1,N11,N2,N21,N5,N51,R51

\begin{abstract}
$\underline{\text { ABSTRACT }}$
Covered mortgage bonds have been used successfully in Europe for two centuries, but failed in the U.S. when introduced as farm mortgage debentures in the 1880 s. Using firm-level data and a sample of loans made by one Kansas mortgage company, I find that debenture programs grew out of established loan brokerage operations and were used to fund mortgages that were difficult to broker because of size, term or risk characteristics. Debentures broadened access to the interregional mortgage market and facilitated an expansion of western farm mortgage debt before the innovation failed in the mortgage crisis of the 1890 s.
\end{abstract}

Kenneth A. Snowden

Bryan School of Business and Economics

P.O. Box 26165

University of North Carolina at Greensboro

Greensboro, NC 27402

and NBER

snowden@uncg.edu 


\title{
Covered Farm Mortgage Bonds in the Late Nineteenth Century U.S.
}

\begin{abstract}
Covered mortgage bonds have been used successfully in Europe for two centuries, but failed in the U.S. when introduced as farm mortgage debentures in the 1880s. Using firm-level data and a sample of loans made by one Kansas mortgage company, I find that debenture programs grew out of established loan brokerage operations and were used to fund mortgages that were difficult to broker because of size, term or risk characteristics. Debentures broadened access to the interregional mortgage market and facilitated an expansion of western farm mortgage debt before the innovation failed in the mortgage crisis of the 1890s.
\end{abstract}

"[T] he availability of affordable mortgage financing is essential to turning the corner on the current housing crisis.... One option we have looked at extensively is covered bonds, which ... have the potential to increase mortgage financing, improve underwriting standards, and strengthen U.S. financial institutions...."

Secretary of Treasury Henry Paulson July 28, 2008

\section{Introduction}

Covered mortgage bonds are debt instruments that are collateralized by a dedicated pool of mortgage loans that the issuer holds on its own balance sheet. The familiar mortgage-backed security (MBS) used in the modern U.S. mortgage market, in contrast, is issued against a pool of mortgages that have been taken off the balance sheet of the institution that originated the loans. ${ }^{1}$ As the MBS market experienced severe distress in 2007 and 2008, the U.S. Department of the Treasury urged market participants to consider covered bonds as an alternative mechanism for funding mortgages. ${ }^{2}$ Secretary Paulson recommended this form of finance because issuers of covered bonds keep more "skin in the game" than participants in MBS structures and so have stronger incentives to maintain strict loan underwriting standards. In making its recommendation the Treasury also pointed to a 200 -year record of success with covered bonds in continental European mortgage markets. This paper offers a different perspective by examining the second of three unsuccessful attempts to introduce covered bonds into the

\footnotetext{
${ }^{1}$ Payments on a MBS are guaranteed by Ginnie Mae, a government-sponsored enterprise, or by credit structures that developed by a private label issuer. The U.S. Treasury ("Best Practices" pp. 9-10) and Rosen ("What are covered Bonds?") compare all the contractual features of the MBS and covered mortgage bonds.

${ }^{2}$ No covered mortgage bonds have been issued in the U.S. since Secretary Paulsen's 2008 statement, but the Treasury's legislative recommendations (U.S. Treasury "Regulatory Reform") include capital requirements for securitizations that are consistent with the development of a covered mortgage bond market.
} 
U.S. mortgage market before 1930 - the "farm mortgage debenture movement" of the 1880 s. $^{3}$ The goal is to explain how the innovation was successfully brought to market, to identify the contribution covered bonds made to the integration of the national farm mortgage market, and to assess the role that debentures played in the western farm mortgage crisis of the 1890 s when nearly every company that had issued the new security failed.

Before 1880 western farm mortgage lending was dominated by mortgage companies that originated loans in the Midwest and Great Plains and then brokered the whole loans to investors in the northeast and Europe. In the 1880s some of these companies began to place mortgages into trust accounts and to issue bonds (called debentures) against this security. An important feature of the debenture movement is that the introduction of these new securities did not simply displace brokerage; instead, the two funding methods were used side-by-side within the same markets and even by the same mortgage companies.

The key to understanding the farm debenture movement as a financial innovation, therefore, is to explain why only some mortgage companies issued covered mortgage bonds and why they were used to fund only some mortgages. The explanation offered here focuses on differences in how risk was shared and how loans were marketed under debentures and brokerage. I argue that only well-established mortgage companies could bear the additional risk that was involved in issuing debentures and that the innovation was then used to fund mortgages that were particularly difficult and costly to broker. These observations are developed in the first section of the paper and then tested empirically on balance sheet data for an 1890 cross-section of western mortgage companies and on an 1887 sample of individual mortgage loans that were either brokered or placed behind debentures by the J.B. Watkins Mortgage Company of Lawrence, Kansas.

\footnotetext{
${ }^{3}$ H.P. Brewer ("Eastern Money") documents unsuccessful attempts by eastern investment bankers and life insurance companies to develop covered mortgage bond programs in the 1870s. D.M. Frederiksen ("Mortgage Banking" and "Mortgage Banking in") provides an account of the debenture movement examined here. Snowden ("Mortgage Securitization") examines both episodes in a history of mortgage securitization in the U.S. before 1930.
} 
The Watkins loan sample also provides an unusual opportunity to explore Secretary Paulsen's claim that covered mortgage bonds provide their issuers with strong incentives to maintain strict loan underwriting standards. It turns out that debentures created a new asymmetry of information in the mortgage market because investors observed less about the loans that were placed behind these bonds than they did about whole mortgage loans that were brokered. The asymmetry provided mortgage companies with an opportunity to apply different loan underwriting standards in the two markets and I find that Watkins used his debenture program to fund loans on which credit risk and lending costs were higher than on the brokered loans he sold outright to investors. I conclude, therefore, that the introduction of covered mortgage bonds broadened the western farm mortgage market and contributed to its rapid expansion just before the onset of the western agricultural mortgage crisis of the 1890s. The demise of the farm debenture movement provides a cautionary lesson about the stability and incentives for credit risk management within covered mortgage bond programs as we once again consider introducing the innovation into the U.S. mortgage market.

\section{Farm Mortgage Banking in the 1880s: From Loan Brokerage to Debentures}

The background to the debenture movement of the 1880s was a pattern of significant regional differentials in mortgage rates during the late nineteenth century that ranged from under six percent in the savings-rich northeast to ten percent or higher in the Great Plains, south and west. Lance Davis first identified these differentials as part of a broad pattern of capital market segmentation and later investigations found that variation in the cost of mortgage credit across space were driven in large part by differences in mortgage lending risk and in the transactions costs associated with lending across regional boundaries. ${ }^{4}$ Both sources of differentials provided opportunities for arbitrage that were taken up by a cadre of specialized mortgage companies that appeared in burgeoning agricultural areas to sell western loans to investors in

\footnotetext{
${ }^{4}$ Following Davis (“The Investment Market"), Eichengreen (“Mortgage Rates") and Snowden (“Mortgage Rates") used different data and methods to investigate the premium in western farm mortgage rates.
} 
eastern and European markets. ${ }^{5}$ Mortgage companies did so by providing distant investors with an entire bundle of services. They hired and supervised loan agents who located borrowers, assembled loan applications, and monitored mortgagors and their land after a loan was closed. The companies hired office staff, meanwhile, to screen applications, to prepare and record loan documents, and to collect and disburse loan payments. ${ }^{6}$

The number and size of these mortgage companies grew rapidly during the 1870 s and 1880 s. The J.B. Watkins Company of Lawrence, Kansas, for example, was established in 1873 but within just seven years claimed an office staff of ten and dozens of loan agents in Kansas, Nebraska and Texas. By then the company sold its loans through offices in New York and London, and employed independent agents who operated in eleven other northeastern cities. ${ }^{7}$ The left panel of Table 1 shows that between 1880 and 1886 Watkins sold more than $\$ 1$ million in loans each year and serviced about $\$ 5$ million of outstanding loans. ${ }^{8}$ In 1887 Watkins added a debenture program to his operation that grew rapidly in size and importance as Watkins placed nearly 40 percent of the loans he marketed behind debentures in the first three years and nearly two-thirds of the loans after 1890 (see the right panel of Table 1). The introduction of a debenture program did not affect the methods that a mortgage company used to originate and service loans. What changed, instead, was the risk-sharing arrangement between the company and investors, the method used to market mortgage loans, and the amount of information about the loans that the company shared with investors. $^{9}$

\footnotetext{
${ }^{5}$ Eastern investors in the 1880s earned nominal returns of $6 \%$ to $7 \%$ on western mortgages when yields on high-grade railroad bonds ranged between $4.6 \%$ and 5.6\% (Carter, Historical Statistics, series Cj1196). Nominal interest rates and loan amounts are reported throughout this paper because the economy experienced gradual deflation of less than $1 \%$ per annum during the 1880s (Ibid, series Cc1-Cc2).

${ }^{6}$ Bogue Money at Interest, p. 85. Bogue's history of Watkins's company is based on business and personal correspondence and the company's business records; I rely heavily on this source throughout the paper.

7 Ibid, pp. 86-90.

${ }^{8}$ The relationship between originations and servicing in Table 1 reflects that nineteenth century farm mortgages were interest-only, balloon loans typically written for five-year terms and frequently renewed (see Mappin "Farm Mortgages"; Snowden "Mortgage Rates").

${ }^{9}$ Two considerations important to modern mortgage securitization were not factors in the $1880 \mathrm{~s}$ - the drive to make mortgages more liquid (secondary markets for debentures did not develop) and the need to spread prepayment risk (loans were short-term and frequently renewed).
} 


\section{Which Companies Issued Debentures? Risk Bearing under Brokerage and Debentures}

Under brokerage the individual investor purchased a whole mortgage loan and owned all the benefits and risks associated with the borrower's promised loan payments. The mortgage company served as the investor's agent in this transaction and was provided with incentives to select and service loans carefully by the same mechanisms that are used in the modern loan sales market — loan participations and recourse agreements. ${ }^{10}$ Participations were created by dividing each brokered loan into a first mortgage that was assigned to the investor and a second lien, junior to the investor's interest, that the company took as a commission. ${ }^{11}$ Recourse provided the mortgage company with additional incentives as it committed to repurchase any loan that went into delinquency. If a borrower missed one payment, a company typically paid the investor from its own funds and sought collection; if the default became persistent, the company repurchased the loan from the investor and initiated foreclosure proceedings on its own behalf. ${ }^{12}$

A mortgage broker committed to repurchasing delinquent loans because it "could not allow client[s] to suffer the loss of a single dollar" without losing their confidence and business. ${ }^{13}$ Maintaining this policy was costly and risky for mortgage companies, but they regularly honored their commitment even though they were not legally bound to do so. ${ }^{14}$ Brokers, instead, offered recourse to investors as a moral or implicit promise that created a flexible risk-sharing arrangement between the two. ${ }^{15}$ Most importantly, mortgage companies could legally suspend recourse in order to preserve financial capital and continue operations even when the borrowers they served came under general distress. If the recourse commitments had been legally

\footnotetext{
${ }^{10}$ Gorton and Pennachi (“Banks and Loan Sales,” p. 394) explain how loan participations and guarantees are used as incentive mechanisms when the seller of a loan provides costly credit services that are unobserved by the buyer.

11 The borrower also paid an up-front commission that the broker shared with his loan agent.

12 Bogue, Money at Interest, pp. 90-92.

${ }^{13}$ Robins, Farm Mortgage, pp. 82-4. Robins spoke as the Vice President of the Farm Mortgage Bankers' Association.

${ }^{14}$ Watkins, for example, hired a full-time attorney in 1883 simply to manage and sell 52,000 acres of farmland that the company had acquired through foreclosure on repurchased loans (Bogue, Money at Interest, pp. 122-3).

${ }^{15}$ Some mortgage companies "guaranteed loans," but committed only to collecting mortgage payments (Darrow, $A$ Treatise, pp. 30-33); others avoided guarantees while emphasizing that they had protected investors by repurchasing failed loans; Bogue (Money at Interest, p. 126) describes Watkins's decision to stop advertising guarantees. For contemporary discussion on recourse see Preston, History of Banking, p.282; Robins, Farm Mortgage, pp. 86-9; Darrow, A Treatise, pp. 29-38.
} 
binding, then these thinly capitalized intermediaries would have failed in the same circumstance. ${ }^{16}$ Investors agreed to a possible suspension of recourse under brokerage, therefore, to avoid sharing the deadweight losses that would have been generated had the loan servicing operation of their mortgage company been disrupted at the very time that loan renegotiation and monitoring would have been most valuable. ${ }^{17}$ To accommodate this solution, mortgage companies built and maintained reputations for suspending recourse only to avoid a costly financial failure. ${ }^{18}$

By issuing debentures a mortgage company strengthened and formalized its risk-bearing obligations. Debentures were debt contracts between the company and investors that were secured by pools of mortgages that the company owned and placed into trust. The company employed a trustee to certify that the loans and supporting documents satisfied criteria stipulated in a trust agreement, but the trustee did not monitor the company's loan origination or servicing operations, guarantee the performance of the loans, or underwrite the company's debentures. ${ }^{19}$ The trustee was required, however, to take possession and to dispose of the underlying mortgage pools on behalf of debenture holders if the company defaulted on its scheduled payments. ${ }^{20}$ Under a debenture program, therefore, investors purchased the debt obligations of a mortgage company that originated and serviced a specified pool of mortgage loans.

The difference in the risk-sharing arrangements under debentures and brokerage helps to explain the timing and character of the farm mortgage debenture movement. Prior to 1880 western mortgage companies

\footnotetext{
${ }^{16}$ Boot et al "Reputation and Discretion") show implicit promises are optimal to use when the deadweight losses associated with financial failure are greater than the reputational costs of reneging on commitments.

${ }^{17}$ Renegotiation with delinquent borrowers can mitigate the deadweight losses associated with forced transfers of land and real property (Fisher "Renegotiation") and Baker et al ("Mortgage Redemption"). Snowden ("The Evolution") attributes the dominance of life insurance companies in interregional mortgage lending after 1890 to the advantages these large investors enjoyed in servicing mortgages if their mortgage company correspondents failed.

18 Robins, (Farm Mortgage, pp. 99-100. Watkins built his reputation during the early 1870s by mailing circulars, placing advertisements in eastern newspapers, corresponding tirelessly with potential investors and even paying for some of them to personally visit Lawrence to inspect his agency and the Kansas farm mortgage market (Bogue, Money at Interest, pp.79-84). He also cultivated and expanded networks within the Quaker church (Ibid, p. 87).

${ }_{19}$ (New York, Annual Report, p. 21). Trust agreements required first mortgage loans written for no more than onehalf the value of improved farmland. The combined principals of the loans in a pool had to fully secure the debentures; between 100 and 200 mortgages were typically required to secure a $\$ 100,000$ issue.

${ }^{20}$ Debenture holders held senior claims on a designated pool of loans and a general claim on the company's unsecured assets. Trustees were required to take possession of the mortgage pool that secured a debenture sixty days after a default, but mortgage companies generally requested receivership in anticipation of default and were often appointed as their own receivers. See Chamberlain, "New-Fashioned") for a description of receiverships during the 1890s.
} 
were too small to originate well-diversified pools of mortgage loans and too poorly capitalized to protect against default, so they relied exclusively on brokerage and implicit recourse agreements, even though debentures were well-known to market participants. ${ }^{21}$ Debentures became feasible in the 1880 s after some farm mortgage brokers had established track records of success and grown in size. Larger size permitted companies to originate more spatially-diversified mortgage pools and to absorb the fixed administrative and legal expenses associated with a debenture operation. A record of success, on the other hand, provided the company with access to lower-cost forms of internal and external financial capital to buffer shocks in the payment stream generated by the mortgage pools. Older, reputable companies were also better positioned, relative to young firms, to market brokered loans alongside, and in support of, their new debenture programs. ${ }^{22}$ For all these reasons the debenture movement was likely to have been an outgrowth of existing, successful mortgage brokerage operations and not an innovation brought to the market by new mortgage companies. ${ }^{23}$ To test this prediction, the pattern of debenture use for a sample of mortgage companies is examined in the next section.

\section{Which Loans were Funded? Marketing under Brokerage and Debentures}

Under debentures the investor, as well as the mortgage company, faced different costs and risks than under brokerage. The investor's expected net return on a brokered loan was influenced by its individual characteristics - its size and term and, given that the company might renege on recourse, its risk characteristics. ${ }^{24}$ Because brokers had to make allowance for investors' preferences over these loan characteristics, the marketing system they employed was cumbersome and costly. Brokers offered mortgages

\footnotetext{
${ }^{21}$ Brewer ("Eastern Money") attributes the failure of covered bonds that were issued by affiliates of eastern investment banks and life insurance companies in the 1870 s to poor control over western loan origination networks - established mortgage companies possessed both financial strength and effective loan agent networks.

${ }^{22}$ A company operating both a brokerage and a debenture program could suspend recourse on brokered loans and divert financial resources to honor its fixed obligations on debentures. Mortgage companies could have used this channel opportunistically, of course, and investors would have been reluctant to purchase a brokered loan from a new, poorly capitalized company that also issued debentures.

${ }^{23}$ The Watkins Company fits this explanation. The company issued debentures years after becoming a large and reputable farm mortgage broker and continued to broker loans even though Watkins had hoped to discontinue brokerage altogether (Bogue, Money at Interest, pp. 130-31).

${ }^{24}$ Loan size and term affected net rate of returns because of the substantial fixed costs investors bore when buying and holding a brokered loan.
} 
to investors on a take-it-or-leave-it basis by provisionally assigning loans to them and mailing the applications and supporting documents back east for their approval. ${ }^{25}$ If a loan was rejected, it had to be reassigned to a second investor. The number of reassignments that Watkins handled each year shown in the second column of Table 1 accounted for slightly less than 10 percent of the brokered loans sold.

The assignment system of marketing brokered mortgage loans imposed substantial costs on both parties. The investor had to expend time and effort, and sometimes employ legal counsel, to assure that their assigned loan was well-secured. The exercise had to be repeated, moreover, if the first loan assigned by the company proved to be unacceptable. ${ }^{26}$ The company spent its own time and effort placing a reassigned loan, of course, but also paid interest to investors on the funds they had invested until a loan was successfully assigned. ${ }^{27}$ Brokers had good reason, therefore, to choose loans that investors were most likely to acceptthose that were typical in legal form, size, maturity and risk characteristics. ${ }^{28}$ Borrowers with loans that fell outside these parameters would have paid a premium to offset higher expected marketing costs, and some loans would have been too irregular to broker at all. ${ }^{29}$ There was room in 1880 , accordingly, for an innovation that could reduce the high and variable costs involved in marketing brokered loans.

Debenture bonds represented a solution because they offered investors an asset that was homogeneous in amount and term, regardless of the characteristics of the individual loans that secured them. ${ }^{30}$ The investor's risk on a debenture, moreover, depended on the income generated by the entire

\footnotetext{
${ }^{25}$ Bogue, Money at Interest, pp. 90-92. In the early 1870s Watkins mailed lists of pending applications east so that investors could select their loans; delay and expense occurred within this alternative system when two investors chose the same loan.

${ }^{26}$ Darrow (A Treatise, pp. 1-5), in his guide for eastern investors, recommends an extensive inspection of loan documents, including a review of the papers by an attorney, before purchasing a brokered loan.

${ }^{27}$ Bogue, Money at Interest, pp. 123-4,

${ }^{28}$ Darrow, A Treatise, pp. 6-18. Robins (Farm Mortgage, pp. 164-96) and published advertisements of western mortgage companies emphasized that brokered loans should only be written on occupied and improved quality farm land with debt-to-value ratios of no more than one-third, or occasionally one-half.

${ }^{29}$ Credit rationing would not have been the only inefficiency associated with brokerage since borrowers might have been forced to alter the amount or term of their loan away from optimal levels in order to meet the standards required to qualify for mortgage credit.

${ }^{30}$ Debentures were generally written for five-year terms, and the loans that secured them could be replaced if they were paid off early or went into delinquency - in modern parlance the underlying mortgage pools were dynamic.
} 
mortgage pool that secured the bond and not on the characteristics of any single loan. ${ }^{31}$ The marketing system used for debentures, as a result, was more efficient and less costly than under brokerage. A single trustee, rather than hundreds of individual investors, evaluated loan applications and mortgage papers; reassignments were eliminated since the company could easily meet the trust requirements that it had written; and each mortgage no longer had to be divided into a first and second note since the company received all of its cash flow. ${ }^{32}$ These simplifications lowered marketing costs relative to brokerage for all mortgages, but the savings would have been greatest for loans that were difficult to broker because of unusual size, term or risk characteristics. To test this prediction, I estimate below the decision rule that Watkins used in 1887 to allocate loans between his debenture and brokerage programs.

The marketing system under debentures was streamlined relative to brokerage, but created an additional asymmetry of information since investors no longer inspected the application and supporting documents for the loans they funded. ${ }^{33}$ Debenture holders relied on three mechanisms to prevent mortgage companies from exploiting this informational advantage: the trust arrangement through which debentures were issued, supervision by state regulatory authorities, and the mortgage company's incentive to uphold underwriting standards in order to protect its own financial and reputational capital.

It turns out that investors relied most heavily on the mortgage company's "skin in the game" because regulation and trust arrangements provided weak supervisory oversight during the 1880 s. Regulation, to begin with, came too late as "foreign" western mortgage companies operating in Connecticut, New York and Massachusetts were not required to report even basic financial data to investors until 1889-years after the debenture movement began to expand rapidly. Even when eastern state regulators published this information, moreover, they cautioned investors that the data were self-reported and that no funding existed for regular on-

\footnotetext{
${ }^{31}$ The loan pool offered investors overcollateralization in the event of default; the loans held in trust carried interest rates higher than the yield promised on the debentures because they had not been "split" into first and second notes. Watkins used this feature of the securities when promoting his own debentures (Bogue, Money at Interest, p. 133).

${ }^{32}$ Darrow, A Treatise, pp. 20-21.

${ }^{33}$ Darrow (A Treatise, p. 23) advised investors to inspect all of the loans placed in trust behind debentures. But Watkins (Bogue, Money at Interest, pp. 130-31) turned out to be correct in predicting that they would not.
} 
sight examinations of the loan underwriting operations of companies located hundreds of miles away. ${ }^{34} \mathrm{I}$

have noted earlier, as well, that the trustees who administered debenture programs for the mortgage

companies were also not required to directly monitor their western lending operations. The first substantial

external examination of western mortgage companies did not occur, in fact, until eastern regulators were

required to audit the companies that entered receivership in the early and mid-1890s. These inquiries

revealed numerous examples of lax underwriting standards and violations of trust agreements that were

particularly egregious when failing companies used all available measures to postpone default. ${ }^{35}$ This

evidence underscores the critical role that the issuer's own "skin in the game" played in controlling the

informational asymmetry that was associated with debentures and that is inherent in any covered mortgage

bond program. The behavior of failing companies tells us much less, of course, about the decisions mortgage

companies made regarding the quality of debenture loans when they were solvent and still had incentives to

maintain strict underwriting standards. I use the Watkins loan sample in the last section of the paper to

examine this important issue.

\section{Which Companies Issued Debentures?}

Table 2 summarizes information that was reported in 1890 to the New York and Massachusetts regulators who supervised the western "foreign" mortgage companies that operated in the two states. ${ }^{36}$ The companies are grouped in the table by the years in which they were organized so that each row reports the group total or average for companies of a particular age. ${ }^{37}$ The data highlight both the success and limits of the debenture movement. On the one hand, debentures were a widely deployed innovation that had a substantial impact on the western farm mortgage market — sixty-two of ninety-nine mortgage companies that

\footnotetext{
34 Massachusetts, Annual Report (1890), pp. 5-7; New York, Annual Report (1891), pp. 15-27.

${ }^{35}$ For accounts of similar abuses by other mortgage companies see New York (Annual Report (1891), pp. 16-9). Snowden ("Mortgage Securitization", pp. 279-81) summarizes regulators' findings and criticisms of both operating and failed farm mortgage debenture companies.

${ }^{36}$ The data were drawn from New York and Massachusetts state reports; a few companies might not have operated in these two most important states. The reports also did not include companies that conducted business through the mail.

${ }^{37}$ The Watkins Company is shown on the first line and in the totals on the second line of the table. Watkins issued debentures later than other older companies, but soon marketed a higher share of loans behind them.
} 
were licensed in these two states had established debenture programs by 1890 . These programs, moreover, together funded one-tenth of the outstanding western farm mortgage debt. ${ }^{38}$ On the other hand, brokerage continued to dominate the western farm mortgage market in 1890. All mortgage companies that issued debentures continued to broker loans, one-third of licensed mortgage companies had still not established covered bond programs, and debentures were used to fund only 19 percent of the total mortgage debt marketed by the licensed companies. A key challenge in understanding the debenture movement of the 1880 s, therefore, is to explain why only some mortgage companies adopted the innovation and why brokerage continued to be so widely used after debentures had appeared.

The discussion in the last section offers a plausible explanation — the western farm mortgage industry had limited capacity to support the introduction of covered bonds because only large, established and financially secure companies could credibly issue their own debt. The descriptive mortgage company data in Table 2 support some elements of this explanation, but contradict others. It was true, for example, that established firms dominated the debenture market as more than 80 percent ( $\$ 40$ million) of the new securities that were outstanding in 1890 were issued by the oldest 37 companies in the industry. Taken together these older firms were also responsible for 75 percent ( $\$ 180$ million) of all the farm mortgage debt handled by licensed companies, so they were also relatively large in size. The grouped data do not appear, however, to support the prediction that the most financially secure mortgage companies issued debentures because they had access to low-cost sources of financial capital. The older firms that issued most of the debentures, in fact, held lower amounts of capital per dollar of outstanding loans than did younger firms that relied almost exclusively on brokerage.

To sort out the pattern of debentures use across the mortgage companies I use the individual firm data underlying Table 2 to examine two decisions that each mortgage company faced in the 1880 s - whether to establish a debenture program and, if so, how large it would grow relative to the company's brokerage business. The analysis relies on a two-part model of debenture usage: a probit model for the decision to

\footnotetext{
${ }^{38}$ The $\$ 48.7$ million of debentures shown in Table 2 is compared here to estimates to the overall size of the western farm mortgage market in 1890 as estimated in Snowden ("Evolution", Table 1).
} 
establish a debenture program and a truncated regression model to explain the shares of loans marketed with the security for the subset of companies that decided to issue debentures. Both models use the same specification:

$$
\begin{aligned}
\text { Debenture Usage }_{\mathrm{i}}=\beta_{0} & +\beta_{1} \cdot \text { Size }_{\mathrm{i}}+\beta_{2} \cdot \text { Capital }_{\mathrm{i}} / \text { Loans }_{\mathrm{i}} \\
& +\beta_{3} \cdot \text { Real Estate }_{\mathrm{i}} \text { /Assets }_{\mathrm{i}}+\beta_{4} \cdot \% \text { Loans Paid }_{\mathrm{i}}+\beta_{5} \cdot \text { Age }_{\mathrm{i}} \\
& +\beta_{6} \cdot \text { South-West }+\beta_{7} \cdot \text { Plains }+\beta_{8} \cdot \text { Northeast }+\mathrm{u}_{\mathrm{i}},
\end{aligned}
$$

where debenture usage is measured with an indicator variable equal to one for the 62 firms that established debenture programs in the probit model, and is set equal to the share of outstanding loans marketed behind debentures in the truncated regression. ${ }^{39}$

The explanatory variables in the specification capture variations in the size, financial strength and reputation of each company, factors that were conjectured earlier to be the important determinants of the capacity to establish a debenture program. Size is measured here as the natural logarithm of the total volume of loans outstanding in 1890; by this metric firms that were established before 1885 were on average five times larger than younger firms (see Table 2). ${ }^{40}$ The financial strength of each company is captured in two ways - by the ratio of paid-in capital to outstanding loans and by the percent of each company's assets that were held in real estate. The latter is included because the most important risk facing western mortgage companies was the losses they could suffer when acquiring and disposing of foreclosed land. We also measure the firm's reputation in two ways - by the natural logarithm of its age and by the percentage of loans marketed by the company that had been successfully paid off by 1890 (see columns 5 and 6 of Table 2). Age should pick up the impacts of longevity, including reputation, that are unrelated to firm size and financial strength, while age and the share of loans paid off are interpreted here as proxies for reputation in brokerage since no firms had issued debentures before 1883. Both reputational variables are expected to be positively related to debenture use.

\footnotetext{
39 The data rejected the alternative Tobit model of debenture usage. See the discussion below.

${ }^{40}$ Total loans outstanding, rather than company assets, is used as a measure of the size of the firm's lending operations because brokered loans were off the company's balance sheet.
} 
Also included in the debenture usage models are dummy variables that indicate the regional location of each company's home office—-52 were headquartered in the Great Plains (the Dakotas, Nebraska and Kansas), 26 in the omitted Midwest region (Minnesota, Iowa and Missouri), eleven in the south and far west, and ten that operated western lending operations from home offices in the Northeast. ${ }^{41}$ These regional fixed effects are included to control for differences in the characteristics of loans that the companies marketed, in the mortgage laws that governed foreclosure in their lending areas, and in the regulatory regimes under which they operated. ${ }^{42}$

The estimates reported in Table 3 reveal why a two-part model, rather than a single Tobit regression, is the preferred specification of debenture usage - measures of company size, financial strength and reputation had different impacts on the decision to establish a debenture program than they did on the choice of how intensively to use it. ${ }^{43}$ The important correlates of the participation decision, as shown in the left panel of Table 3, were firm size and financial strength as measured by the amount of paid-in capital per dollar of loans marketed. The impact of size was large as well as statistically significant: a one unit increase from the mean (that is, from $\$ .89$ to $\$ 3.3$ million of loans) increased the probability of establishing a debenture program by 38 percent. The significant positive association between debenture use and financial capital in the probit regression, moreover, stands in contrast to the misleading as well as counterintuitive pattern in the group averages shown in Table 2 - firms that issued debentures held more, not less, financial capital per dollar of outstanding loans after controlling for firm size. Both results suggest that the debenture movement grew out of established brokerage businesses because these firms could reduce the probability of defaulting

\footnotetext{
${ }^{41}$ Regional rather than state dummies are included in the specification because five states in the "South and West" and "Eastern" groups had only one operating mortgage company (California, Georgia Massachusetts, Vermont and Washington) while all of the companies operating in Connecticut and Texas issued debentures. Because of these data limitations, regional effects for these two regional groupings are not interpreted here. The results reported below, however, also hold for models with individual state dummies fitted for the "Great Plains" and "Midwestern" groups.

${ }^{42}$ We have seen earlier that mortgages of unusual size, term and risk would have gained most from being funded with debentures. The state regulatory reports provided no information about the average characteristics of the loans marketed by each company, and the regional dummies can also be interpreted as controls for this variation.

${ }^{43}$ The Tobit model assumes each variable has the same affect on the latent variable - the share of loans securitizedabove and below zero while the two-part model permits variables to have different impacts on the decision to establish a debenture program and the share of loans to fund with it. The Tobit model was rejected at the $\mathrm{p}=.01$ level using the likelihood ratio test from Greene (Econometric Analysis, p. 770); the truncated regression corrects the standard errors of the coefficient estimates for the excluded observations.
} 
by assembling spatially diversified loan pools and backing the promised payments from them with greater amounts of financial capital. ${ }^{44}$

The estimates of the truncated regression shown in the right panel of Table 3 indicate that a different set of factors explains how intensively companies used their new debenture programs. As expected, higher levels of capital were associated with a greater reliance on debentures after the innovation was adopted, but company size had no statistically significant impact on the share of loans marketed behind the new securities. The intensity of debenture use also increased with company age and decreased with the share of assets held in real estate, although neither measure had a statistically significant impact on the probability of issuing the securities in the first place. These last two impacts suggest that reputation and past performance were important determinants of the willingness of investors to accept a particular debenture issue once a program had been established. Older mortgage companies had by the late 1880 s maintained successful loan brokerage operations for a decade or more, while companies that held low amounts of foreclosed real estate on their balance sheet had shown that they could select mortgages carefully and service them responsibly.

The mortgage company data indicate, therefore, that debenture programs tended to be established by large and financially secure mortgage companies and that the securities were then used most intensively by companies that had strong records of past performance. The debenture movement of the 1880 s grew alongside, and out of, the brokerage loan system that dominated the western farm mortgage market.

\section{What Types of Loans were Funded with Debentures?}

After establishing its debenture program in 1887, the Watkins Company had to decide—like other mortgage companies that adopted the innovation — which mortgages to place behind covered bonds and which ones to broker. In this section I examine that decision for a sample of 689 loans that Watkins made

\footnotetext{
${ }^{44}$ The coefficients on the regional dummies also suggest, not surprisingly, that debentures were adopted disproportionately by mortgage companies headquartered in the Great Plains.
} 
and marketed in the first year of his debenture program. ${ }^{45}$ These mortgages were typical of loans that Watkins had brokered since opening his company in 1873 as they were all written on Kansas farmland and negotiated through the company's established loan agent system. The data for each loan, moreover, was drawn from the company's original mortgage ledger so that we observe the same information for these loans that the company's personnel recorded as 465 of these loans were being brokered and the remaining 224 were assigned to the company’s debenture program. ${ }^{46}$ I use the loan sample in this section to assess how and why this allocation was made.

The descriptive statistics for the brokered and debenture loans are shown separately in Table 4. Both groups were written on farms that averaged just less than 150 acres in size, but debenture loans were smaller in size (an average of $\$ 536$ versus $\$ 628$ ) and so carried lower average debt-per-acre ( $\$ 3.76$ to \$4.51). Debenture loans were also written more often for short, three-year terms, for unusually small amounts (less than \$400), and on farms that were located in western Kansas, in recently settled counties of the state, or far away from Watkins's Lawrence office. ${ }^{47}$ Watkins expanded his new program quickly in 1887 so that the proportion of loans that were brokered fell from three-quarters to one-third between the first and fourth quarters of the year.

The bottom panel in Table 4 shows the average effective interest rates borrowers were charged and the average gross rates of return to be paid under the contracts to Watkins, his loan agents and investors for both brokered and debenture loans. ${ }^{48}$ These data reveal two interesting patterns. First, Watkins's average contractual rate of return on debenture loans was 98 basis points higher than on

\footnotetext{
${ }^{45}$ Watkins planned to issue $\$ 10.2$ million debentures between 1887 and 1893 and actually issued most of them before the company entered receivership in April, 1894 (see Table 1).

${ }^{46}$ Excluded from this sample were loans that Watkins made in Texas and Louisiana, loans made outside Watkins's normal lending network, and nearly 100 mortgages on farms in western Missouri and eastern Kansas; 90 percent of Watkins's mortgages were located in the western two-thirds of the state in 1890.

${ }^{47}$ The miles-from-Watkins variable is the distance between Lawrence and the center of each borrower's townshiprange section. The West Kansas region includes counties within 80 miles of the state's western boundary. Specification tests indicated that additional regional dummies were not required.

${ }^{48}$ The effective interest rate is the sum of average annual interest and commission payments divided by the discounted loan amount - a measure close to the true yield to maturity for these non-amortized loans. The gross rates of return under the contract were computed from the commission payments, interest charges and loan amounts as they were recorded in Watkins's ledgers. The gross returns for the investor, Watkins and the loan agent do not add up to the effective interest rate because they were calculated relative to undiscounted loan amounts. The investor's gross contractual return on a debenture loan was the coupon rate on the debentures that it secured.
} 
brokered loans. The reverse was true for investors as their average gross rate of return on brokered loans was 58 basis points higher than the return on debentures. Second, the average mortgage rate on loans placed behind debentures was 68 basis points higher than the average rate on brokered loans. This differential indicates systematic differences in lending costs and risks across the two programs and accounting for these turns out to be an essential first step in understanding and interpreting Watkins's debenture selection rule.

\section{Mortgage Rates and Foreclosure within the Loan Sample}

The effective interest rate that Watkins charged his borrowers can be modeled as a hedonic function of loan terms, borrower location and local mortgage market conditions ${ }^{49}$ :

$$
\begin{gathered}
\text { Rate }_{\mathrm{i}}=\beta_{0}+\beta_{1} \text { Debenture }_{\mathrm{i}}+\sum_{\mathrm{j}=2}^{5} \beta_{\mathrm{j}} \text { Loan Terms }_{\mathrm{ji}}+\sum_{\mathrm{k}=6}^{8} \beta_{\mathrm{k}} \text { Loan Location }_{\mathrm{k}} \\
+\sum_{\mathrm{m}=9}^{14} \beta_{\mathrm{m}} \text { Market Conditions }_{\mathrm{mi}}+\mathrm{u}_{\mathrm{i}}
\end{gathered}
$$

The first group of regressors controls for the impacts that loan size, term-to-maturity and debt-per-acre had on the borrower's costs of funds. Because mortgage origination and marketing entailed fixed costs, the effective rate should have decreased with loan size and contract length; rates should have also increased with the borrower's leverage as measured here by the debt-per-acre. Three location regressors are also included in the specification to capture variations across space in agricultural risk, in lending risk, and in monitoring costs during this decade of rapid agricultural settlement in Kansas: the distance between the borrower and Watkins's Lawrence office and indicators for loans that were made in Western Kansas or in a newly settled county. ${ }^{50}$ The remaining six variables control for temporal, local or firmlevel influences on mortgage rates_quarterly dummies to control for seasonal impacts, Watkins's share

\footnotetext{
${ }^{49}$ Specification tests revealed no statistically significant interactions among loan terms (size, maturity and debt per acre), among location variables and debt per acre, and between debenture status and all loan terms and location variables. See Snowden ("Mortgage Rates") for a similar hedonic specification explaining county-level mortgage rates drawn from 1890 census data.

${ }^{50}$ Counties are identified as "Newly Settled" if no mortgage lending activity occurred there in 1880 as reported in the U.S. Census, Report on Real Estate Mortgages.
} 
of lending and previous foreclosure experience in each county, and an indicator for the participation of one of Watkins's high-volume loan agents. ${ }^{51}$ Finally, debenture status is included to capture the remaining unexplained difference in average rates on debenture and brokered loans.

The estimated hedonic model, reported in the first two columns of Table 5, explains nearly threefourths of the variation in the borrower's cost of funds - and the entire 68 basis point differential between average mortgage rates on brokered and debenture loans. The latter result makes sense because borrowers in a competitive primary farm mortgage market would have refused to pay a premium based simply on how their loans were to be funded. The hedonic specification is also recommended by the reasonable signs and magnitudes of other estimated coefficients, such as the 20 basis point reduction in the rate for a large-sized loan and a 39 basis point increase in rates for a short-term loan. ${ }^{52}$ The locational measures of production and lending risk, moreover, trace out a sensible spatial pattern of lending risk premia that ranges from 200 basis points in the more settled areas of central Kansas to nearly 400 basis points in the most western areas of the state; borrowers also paid a 48 basis point premium if they were located in a newly settled county. Rates were significantly lower in markets in which Watkins's own lending was heaviest, but were unaffected by the other company-related measures of local market conditions. ${ }^{53}$ The coefficients on the quarterly dummies, finally, indicate that rates charged to borrowers fell by 60 basis points over the course of the year.

An unexpected result in Table 5 is that the debt-per-acre on loans had a small and statistically insignificant impact on mortgage rates. This variable was included because the actual loan-to-value ratio,

\footnotetext{
${ }^{51}$ Watkins's market share is his lending volume in each county between 1883 and 1886 divided by county-wide total mortgage lending as reported in the U.S. Census, Report on Real Estate Mortgages. His share was no larger than 5 percent for any county, so the variable should not be interpreted as a measure of market power. A "Big Agent" dummy was assigned to the eight loan agents with the highest volume between 1883 and 1886 . The foreclosure dummy indicates if any loan held by Watkins within the same county had been "deeded" or was "in suit" in 1886.

${ }^{52}$ To recoup $\$ 20$ in fixed costs on a $\$ 600$, five-year loan a borrower would have to be charged 66 basis points per year, 50 basis points for a five-year $\$ 800$ dollar loan, and 110 basis points for a three-year $\$ 600$ loan -all are very close in magnitude to the estimated coefficients in the model. The effect of short maturities might also reflect a reinvestment risk premium since the general level of western mortgage rates declined gently throughout the 1880s. ${ }^{53}$ The predicted rate was 73 basis points lower in the county in which Watkins lent the greatest volume $(\$ 203,000)$ indicating either company-specific economies of scale or strong competition from other companies in these counties.
} 
which is the traditional measure of mortgage lending risk, was not available for the sample. ${ }^{54}$ Debt-peracre could be a poor proxy for actual leverage, of course, if the remainder of the specification does not adequately control for variation in land values across the sample. It is also likely, moreover, that lenders adjusted the term and size of a mortgage, as well as absolute debt levels, to control lending risk.

As a check on the specification of ex ante lending risk in the mortgage rate equation, the last three columns of Table 5 examine how well the same set of regressors predict the likelihood of foreclosure for the loans in the sample. ${ }^{55}$ The probit model reported there (the dependent variable equals one if Watkins subsequently foreclosed on the loan) employs the same hedonic specification used in the mortgage rate model but this time augmented with two county-level measures of mortgage market disruption for the threeyear period after the loans were made - the percentage change between 1887 and 1889 in the number of acres mortgaged and in the debt-per-acre on new mortgage loans. Both should have decreased if general mortgage distress spread within a county. ${ }^{56}$

The estimates of the probit model show that two of the locational measures of risk from the mortgage rate regression affected the probability of foreclosure several years later in the expected direction — the probability increased with distance from Watkins's office and was higher for loans made within a newly settled county. The results also reveal, as expected, that foreclosure was more likely for loans that were located in counties where the debt-per-acre on new loans decreased between 1887 and 1889 . On the other hand, the probability of foreclosure was lower, just like mortgage rates, in counties where Watkins lent large volumes of funds. These results provide confidence that the hedonic mortgage rate specification captures fundamental lending risk as it was priced and ultimately felt in the primary mortgage market. ${ }^{57}$

Against this backdrop the behavior of the debt-per-acre variable in the foreclosure equation is striking - it was strongly, positively and statistically significantly associated with the probability of

\footnotetext{
${ }^{54}$ The amount of land, and not its appraised value, was recorded in the company's ledgers.

${ }^{55}$ The foreclosure status for each loan was reported in ledgers called "Mortgages Maturing" as well as records of foreclosed lands. Loans that were "deeded" or "in suit" were classified as foreclosed.

${ }^{56}$ The number and amount of farm mortgage debt made on farms in 1887, 1888 and 1889 were drawn from the U.S. Census, Report on Real Estate Mortgages.

${ }^{57}$ The negative impact of small loan size on foreclosure, and the similarly-sized, weaker impact of a short loan term, could reflect that such loans tended to be paid off before the impact of the mortgage crisis was felt in the early 1890s.
} 
foreclosure even though it had no impact on the effective mortgage rate when these loans were actually being written. This pattern suggests that debt-per-acre was an effective measure of lending risk, at least after origination, and provides evidence that Watkins may have accepted some loans that violated his own conservative standard of holding loan-to-value ratios below fifty percent. ${ }^{58}$ Bogue reports convincing evidence, in fact, that the Watkins Company was under competitive pressure from other lenders to approve poorly secured loans in $1887 .{ }^{59}$ The evidence of market-wide pressures on underwriting standards during the late 1880 s makes it particularly interesting to assess how Watkins, and presumably other mortgage companies, assigned loans to their debenture programs.

\section{Selecting Loans for Debentures}

An important feature of the Watkins's sample is that it contains the information investors in the brokered loan market would have observed about each mortgage whether it was brokered or placed behind the company's debentures. ${ }^{60}$ To take advantage of this feature of the data, two probit models of debenture status are reported in Table 6. The model in the left panel of the table uses the entire hedonic specification from the effective interest rate to explain debenture status while the second includes only those variables within the hedonic specification that an investor would have observed had the loan been

\footnotetext{
${ }^{58}$ Demyanyk and Van Hemert ("Understanding") have shown similar behavior by mortgage loan originators between 2005 and 2007 who became aware of a gradual decrease in the quality of residential mortgage loans that they made. Mappin ("Farm Mortgages," p. 440) provides evidence that similar lending pressures appeared in 1887 with the arrival of a "flood" of eastern orders for western farm mortgages.

${ }^{59}$ The supervisor of Watkins's loan agents wrote in 1887 that: "The great trouble is the competition ....in the amounts other companies are willing to loan... [t] here is certainly a line beyond which...land will not be sufficient security, and we think a great many of the loaning companies ... are lending more money than the farms are sufficient security for" (Bogue, Money at Interest, p. 142). Bogue (Ibid, pp. 141-4) then recounts the difficulty Watkins had in approving enough loans to satisfy his loan agents; so much so that a company official wrote in 1888 that "[o]ne year ago sub agents and borrowers run [sic] the loaning business in this state about to suit themselves" (Ibid, p. 144).

${ }^{60} \mathrm{~A}$ plausible alternative for debenture selection that was not supported by the evidence is that Watkins chose loans behind debentures in response to differences in the gross rates of return that investors required for each loan in the two markets. This alternative was examined for the loan sample by modeling the investors' gross returns as functions of the hedonic specification separately for both debenture and brokered loans. Loan characteristics or measures of risk did not influence investors' returns in either case and so would not have affected Watkins's selection decision. These results make sense in light of the marketing systems described earlier-brokered loans were offered to investors on a take-it-or-leave-it basis, while investors could not observe the characteristics of loans placed behind debentures.
} 
brokered. We refer to this smaller subset of variables as the "Mortgage Papers Information" set, and the estimates in Table 6 indicate that only these loan features were associated with debenture selection. ${ }^{61}$

The importance of the mortgage papers information set in debenture selection, coupled with the interpretation of the individual coefficient estimates in the probit model, represents strong evidence that Watkins used his covered mortgage bond program to fund loans that would have been difficult and costly to broker. Investors would have avoided buying small and short-term loans, for example, unless they received a higher rate of return to compensate for the substantial fixed costs they bore under brokerage. Watkins tended to place these loans behind his debentures. Large-sized loans should have been preferred in the brokered market for the same reason and, as expected, had low probabilities of being funded with covered bonds. Investors would have been particularly cautious purchasing brokered loans with high idiosyncratic lending risk such as those made in Western Kansas or far away from Watkins's Lawrence office - but Watkins placed these types of loans behind the company's new securities. These patterns of debenture assignment are all consistent with the hedonic mortgage rate regression in that the same loan characteristics that raised lending costs and risks in the primary mortgage market also increased the probability of a loan being placed behind debentures. Together these results provide compelling evidence that debentures were used to provided a funding channel to serve borrowers who were most poorly served by the brokered loan system.

The debt-per-acre variable follows a different pattern as Watkins avoided brokering loans with relatively high levels of debt per acre even though this proxy for the true debt-to-value ratio had no impact on expected lending costs and risks as captured in the hedonic mortgage rate model.. On the other hand, we have seen earlier that loans with high levels of debt per acre had higher probabilities of foreclosure and that Watkins felt competitive pressure to approve loans with high loan-to-value ratios in 1887. Taken together the pattern of evidence suggests that Watkins used his new debenture program not only to fund loans that had always been risky and costly to broker, but also to fund mortgages that were made under relaxed mortgage lending standards during the western farm mortgage lending boom of the

\footnotetext{
${ }^{61}$ The likelihood ratio test $\left(\chi^{2}(4)=2.94\right)$ cannot reject the null of equivalence between the two nested probit models.
} 
late 1880 s. If so, this evidence provides an important cautionary note to claims that an issuer's "skin in the game" under the covered mortgage bond contract provides strong incentives to maintain lending standards because the Watkins Company was a solvent, well-established and reputable mortgage company in 1887.

Watkins could use debentures to market relatively high-cost and high-risk mortgages because, as explained earlier, covered bonds packaged the costs and risks on mortgage loans differently than brokerage. To demonstrate this feature of the innovation, Table 7 reports the sources of the differentials in the average effective mortgage rates for debenture and brokered mortgages in the sample and in the differences in the average gross rates of return that each market participant was to be paid under the contracts for the two groups of loans. In the first column of Table 7 the differential in average effective mortgage rates has been decomposed into four components by using the in-sample predictions from the earlier hedonic mortgage rate regression. That calculation reveals that higher lending costs and risks on debenture loans (as measured by loan terms, size, maturity and location) explain 76 basis points of the differential in average mortgage rates between brokered and debenture loans while differences in market conditions (that measure the strength of local demand and supply) reduced the differential by an average of 9 basis points. After controlling for these influences, debenture status itself explains none of the average differential in mortgage rates between the two types of loans.

To sort out how the debenture contract allocated these differences in lending costs and risks among the parties, the same hedonic specification was used to model the gross contractual return earned by Watkins, his loan agents and investors. These three regressions are reported in Appendix Table 1 and, as above, the in-sample predictions from them were used to decompose the differential between loan types in average gross returns for each group. ${ }^{62}$ Three patterns stand out. First, the debenture contract

\footnotetext{
${ }^{62}$ The average gross rates of return under contract for Watkins, his agent and the investor for debenture and brokered loans are reported in the bottom panel of Table 4-the exercise reported in Table 7 simply decomposes the differentials between the two. Recall (see note 48) that the effective mortgage rate does not equal the sum of the three gross rates of return because the former is calculated using the loan amount net of commissions. The mortgage rate and three gross return equations are, nonetheless, a seemingly unrelated system. Each equation has been
} 
directed all of the payments borrowers agreed to as compensation for higher lending costs and risks to Watkins and his loan agents. ${ }^{63}$ This pattern made sense because investors bore none of these loanspecific costs or risks while holding debentures that were secured by these mortgages. Second, all three groups shared the relatively small decreases in gross returns on debenture loans, relative to brokered loans, that were associated with differences in the local market conditions under which they were negotiated. Finally, Watkins's gross return increased by 54 basis points, and investors' fell by a nearly identical amount, when a mortgage loan—regardless of its lending risk, costs or market characteristicswas placed behind a debenture. This shift in returns compensated mortgage companies for the costs associated with establishing trusts, issuing securities, and holding additional financial capital when they issued debentures. Investors in covered bonds, on the other hand, received lower gross returns than on brokered loans because they no longer had to evaluate, purchase and hold an individual mortgage or bear the risk on it.

\section{Conclusion}

The debenture movement of the 1880s involved the introduction of covered mortgage bonds as an alternative to a loan brokerage system that up until then had dominated the interregional farm mortgage market in the United States. Western mortgage companies adopted the innovation in order to provide investors with greater risk sharing and lower transactions costs than were available under brokerage, but by holding loans and issuing bonds against this security these firms increased the probability of their own financial failure. These basic insights have been used here to explain both the timing and the contribution of the debenture movement. First, mortgage companies did not issue debentures until the 1880s because before then they were not large enough or sufficiently well-capitalized to issue their own securities. Second, debentures improved the efficiency of the interregional mortgage market, and broadened access to it, by

estimated separately here because GLS procedures are no more efficient when identical sets of regressors are used (Greene, Econometric Analysis, p. 343).

${ }^{63}$ To provide incentives to find good borrowers, mortgage companies paid agents fixed commission only after a loan application was approved. Agents were then expected to service and enforce outstanding loans with no additional compensation, so they shared in the lending risk and had to be compensated for it (Snowden, "Evolution," pp. 221-5). 
creating a funding mechanism for loans that were difficult and costly to broker because of unusual size, term to maturity or risk characteristics. Lance Davis conjectured more than four decades ago that mortgage companies were instrumental to the regional integration of the farm mortgage market. ${ }^{64}$ The analysis presented here clarifies both the timing and character of their contribution.

The broader access provided by debentures helped to finance a rapid expansion of mortgage debt in western agricultural markets during the 1880s. During that expansion we have seen that Watkins, and presumably other mortgage companies, profited by placing riskier loans behind debentures than the ones he brokered. This feature of the debenture movement proved to be a double-edged sword when weather shocks and financial panic in the early 1890s wreaked havoc in the western farm mortgage market. The crisis drove the Watkins agency into receivership along with 89 of the 98 other mortgage companies that had been licensed to operate in New York and Massachusetts in 1890 (see the third column of Table 2). It is difficult to argue, therefore, that the use of covered mortgage bonds strengthened mortgage companies or provided them with strong incentives to resist a general weakening of mortgage lending standards during the 1880s. The debenture movement, therefore, represents a cautionary tale as we once again consider introducing covered bonds to the U.S. mortgage market.

\footnotetext{
${ }^{64}$ Davis "The Investment Market".
} 


\section{REFERENCES}

Baker, Mathew, Thomas J. Miceli, and C.F.Sirmans, "An Economic Theory of Mortgage Redemption Laws," Real Estate Economics 36, no. 1 (2008): 31-45.

Bogue, Allan. Money at Interest. Ithaca, NY: Cornell University Press, 1955.

Boot, Arnoud W. A., Stuart I. Greenbaum, and Anjan V. Thakor. "Reputation and Discretion in Financial Contracting." American Economic Review 83, no. 5 (1993): 1165-83.

Brewer, H.P. "Eastern Money and Western Mortgages in the 1870s." Business History Review 50, no. 3 (1976): 356-380.

Carter, S.B., S. Gartner, M. Haines, A. Olmstead, R. Sutch, and G. Wright, eds. Historical Statistics of the United States. New York: Cambridge University Press, 2006.

Chamberlain, D.H. "New-Fashioned Receiverships.” Harvard Law Review 10, no. 3 (1896): 139-49.

Chamberlain, Lawrence, and George W. Edwards. The Principles of Bond Investment. New York: Henry Holt, 1927.

Darrow, Edward N. A Treatise on Mortgage Investments. Minneapolis, 1892.

Davis, Lance. (1965). "The Investment Market, 1870-1914: The Evolution of a National Market." This JOURNAL 33, no. 3 (1965): 355-393.

Demyanyk, Yuliya and Otto Van Hemert, "Understanding the Subprime Mortgage Crisis." Review of Financial Studies, published on May 4, 2009 as doi:10.1093/rfs/hhp033, available at http://rfs.oxfordjournals.org/papbyrecent.dtl].

Barry Eichengreen. "Mortgage Rates in the Populist Era," American Economic Review 74, no. 5 (1984): 9951015.

Fisher, Lynn. "Renegotiation in the Common Law Mortgage and the Impact of Equitable Redemption." Journal of Real Estate Finance and Economics 32, no. 1 (2006): 61-82.

Frederiksen, D.M. "Mortgage Banking." Journal of Political Economy 2, no. 2 (1894): 203-34.

Frederiksen, D.M. "Mortgage Banking in Germany." Quarterly Journal of Economics 9, no. 1 (1894): 47-76.

Gorton, Gary and G. Pennachi. "Banks and Loan Sales: Marketing Nonmarketable Assets." Journal of Monetary Economics 35, no. 3 (1995): 389411.

Greene, William. Econometric Analysis. ( $4^{\text {th }}$ ed.). Upper Saddle River, NJ: Prentice Hall, 2003.

Herrick, Myron, and R. Ingalls. Rural Credits. New York: D. Appleton, 1915.

Mappin, W.F. "Farm Mortgages and the Small Farmer.” Political Science Quarterly 4, no. 3 (1889): 433-51.

Massachusetts. Annual Reports of the Commissioner of Foreign Mortgage Corporations. Boston, MA, 189095.

New York. Annual Report of the Superintendent of Banks Relative to Foreign Mortgage, Loan, or Investment Companies. Albany, NY, 1891-97.

Preston, Howard H. History of Banking in Iowa. Iowa City, IA: University of Iowa Press, 1922.

Robins, Kingman. The Farm Mortgage Handbook. New York: Doubleday, 1916.

Rosen, Richard J. "What are covered bonds?" Chicago Fed Letter, No. 257 (2008): 1-4. 
Snowden, Kenneth. "Mortgage Rates and American Capital Market Development in Late Nineteenth Century." This JOURNAL 47, no. 3 (1987): 671-692.

Snowden, Kenneth. "Evolution of Interregional Mortgage Lending, 1870-1940: The Life Insurance-Mortgage Company Connection." In Coordination and Information: Historical Perspectives on the Organization of Enterprise, edited by N. Lamoreaux and D. Raff, 209-247. Chicago: University of Chicago Press, 1995.

Snowden, Kenneth. "Mortgage Securitization in the United States: Twentieth Century Developments in Historical Perspective." In Anglo-American Financial Systems: Institutions and Markets in the Twentieth Century, edited by M. Bordo and R. Sylla, pp. 261-298. New York: New York University, 1995.

U.S. Census Office. Census of Population.Vol. 12. The Report on Real Estate Mortgages in the United States. Washington, D.C.: GPO, 1895.

U.S. Department of the Treasury. Best Practices for Residential Covered Bonds. Washington, D.C. (2008). Available online at http://www.treas.gov/press/releases/reports/USCoveredBondBestPractices.pdf

U.S. Department of the Treasury. Financial Regulatory Reform: A New Foundation. Washington, D.C. (2009). Available online at http://www.financialstability.gov/docs/regs/FinalReport_web.pdf. 


\section{TABLE 1}

J.B. Watkins Mortgage Brokerage and Debenture Operations

\begin{tabular}{|c|c|c|c|c|c|c|c|}
\hline \multirow[b]{4}{*}{ Year } & \multicolumn{3}{|c|}{ Watkins' Brokerage Business } & \multicolumn{4}{|c|}{ Watkins' Securitization Business } \\
\hline & \multirow{2}{*}{\multicolumn{2}{|c|}{ Number of Loans: }} & \multirow{3}{*}{$\begin{array}{c}\text { Total } \\
\text { Amount } \\
\text { Made } \\
(\$ 000 s) \\
\end{array}$} & \multicolumn{2}{|c|}{ Debentures } & \multicolumn{2}{|c|}{$\begin{array}{l}\text { Loans Placed In } \\
\text { Trust: }\end{array}$} \\
\hline & & & & Number & Face & Number & Total \\
\hline & Brokered & Reassigned & & Series & $\begin{array}{c}\text { Amount } \\
(\$ 000 s)\end{array}$ & & $\begin{array}{c}\text { Amount } \\
(\$ 000 \mathrm{~s}) \\
\end{array}$ \\
\hline 1880 & 1,126 & (220) & 635.6 & -- & -- & -- & -- \\
\hline 1881 & 1,675 & (323) & $1,018.1$ & -- & -- & -- & -- \\
\hline 1882 & 859 & (76) & 607.8 & -- & -- & -- & -- \\
\hline 1883 & 968 & (65) & 894.8 & -- & -- & -- & -- \\
\hline 1884 & 1,278 & ( 58$)$ & $1,105.2$ & -- & -- & -- & -- \\
\hline 1885 & 1,669 & (79) & $1,433.8$ & & -- & 20 & 15 \\
\hline 1886 & 1,970 & (140) & $1,685.3$ & -- & -- & 231 & 182 \\
\hline 1887 & 1,039 & (101) & 963.6 & & 800 & 602 & 515 \\
\hline 1888 & 540 & (41) & 557.5 & 10 & 1,000 & 381 & 605 \\
\hline \multirow[t]{3}{*}{1889} & 539 & (45) & 865.5 & 10 & 1,000 & 343 & 611 \\
\hline & \multicolumn{3}{|c|}{ All Loans 1880-1889 } & \multicolumn{4}{|c|}{ All Loans 1880-1889 } \\
\hline & 11,663 & $(1148)$ & 9,767 & 20 & 2,800 & 1,577 & 1,927 \\
\hline 1890 & 329 & (17) & 447.4 & 10 & 1000 & 326 & 739 \\
\hline 1891 & 125 & (17) & 107.5 & & & 522 & 761 \\
\hline 1892 & 91 & (17) & 100.0 & 64 & $\{6400\}$ & 375 & 409 \\
\hline \multirow[t]{3}{*}{1893} & 208 & (13) & 299.0 & & & 108 & 165 \\
\hline & \multicolumn{3}{|c|}{ All Loans 1890-1893 } & \multicolumn{4}{|c|}{ All Loans 1890-1893 } \\
\hline & 753 & (64) & 954 & 10 & 7,400 & 1,331 & 2,074 \\
\hline
\end{tabular}

Notes: Mortgages placed in trust could be reassigned to different series and were valued at the original face value of the loan. The number of debenture series and loans that Watkins planned to issue between 1891and 1893 is shown in the right panel. The company records are unclear concerning how many of these were actually issued prior to the company's receivership.

Sources: The number and amount of mortgages sold by the Watkins Company were drawn directly from the company's original mortgage ledgers. 
TABLE 2

Western Mortgage Loan Companies Operating in Massachusetts and New York in 1890

\begin{tabular}{|c|c|c|c|c|c|c|c|c|c|c|c|c|}
\hline \multirow{3}{*}{$\begin{array}{l}\text { Age of Companies } \\
\text { (Year Established) }\end{array}$} & \multicolumn{3}{|c|}{ Number of Companies } & \multicolumn{3}{|c|}{$\begin{array}{c}\text { Cumulative Loan } \\
\text { Volume }\end{array}$} & \multicolumn{4}{|c|}{ Totals in 1890 (\$ millions) } & \multicolumn{2}{|c|}{ Percent of Loans } \\
\hline & Licensed & Issuing & Licensed & $(\$ \mathrm{mi}$ & ons) & Per & Assets & Out- & Deb- & $\begin{array}{l}\text { Paid- } \\
\text { In }\end{array}$ & & \\
\hline & In & Deben- & In & Made & Paid & Cent & & standing & entures & Capital & Deb- & $\begin{array}{l}\text { Paid- } \\
\text { In }\end{array}$ \\
\hline & 1890 & tures & 1896-97 & & Off & Paid & & Loans & Issued & & entures & Capital \\
\hline
\end{tabular}

\section{J.B. Watkins Company}

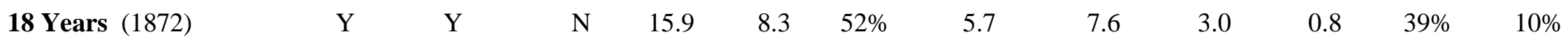

\section{All Companies (Including Watkins)}

\begin{tabular}{|c|c|c|c|c|c|c|c|c|c|c|c|c|}
\hline 11-20 yrs. (1872-79) & 14 & 11 & 4 & 107.1 & 52.6 & $49 \%$ & 27.5 & 54.5 & 16.4 & 5.6 & $30 \%$ & $10 \%$ \\
\hline 6-10 yrs. (1880-84) & 23 & 19 & 3 & 186.2 & 49.6 & $27 \%$ & 47.7 & 136.6 & 24.2 & 10.8 & $18 \%$ & $8 \%$ \\
\hline 5 yrs. (1885) & 15 & 9 & 1 & 34.1 & 8.0 & $23 \%$ & 11.5 & 26.1 & 5.5 & 3.6 & $21 \%$ & $14 \%$ \\
\hline 4 yrs. (1886) & 12 & 9 & & 24.0 & 9.1 & $38 \%$ & 5.2 & 14.9 & 1.7 & 2.5 & $11 \%$ & $16 \%$ \\
\hline 3 yrs. (1887) & 11 & 5 & 1 & 10.0 & 1.6 & $16 \%$ & 3.2 & 8.4 & 0.4 & 1.5 & $5 \%$ & $18 \%$ \\
\hline 2 yrs. (1888) & 11 & 4 & & 5.5 & & $6 \%$ & 2.5 & 5.1 & 0.2 & 1.3 & $4 \%$ & $25 \%$ \\
\hline 1 yr. (1889) & 13 & 5 & & 5.3 & 0.4 & $8 \%$ & 2.5 & 4.9 & 0.4 & 1.4 & $8 \%$ & $29 \%$ \\
\hline Total & 99 & 62 & 9 & 372.2 & 121.7 & $33 \%$ & 100 & 250.5 & 48.7 & 26.7 & $19 \%$ & $11 \%$ \\
\hline
\end{tabular}

Source: Massachusetts: Annual Report of the Commissioner of Foreign Mortgage Corporations, First (1890) and Second (1891).

New York: Annual Report of Superintendent of Banking, Relative to Foreign Mortgage, Loan and Investment Companies, 1891. 


\section{TABLE 3}

Determinants of Issuing Debentures and Share of Loans Behind Debentures in 1890 99 Western Mortgage Loan Companies Operating in Massachusetts and New York

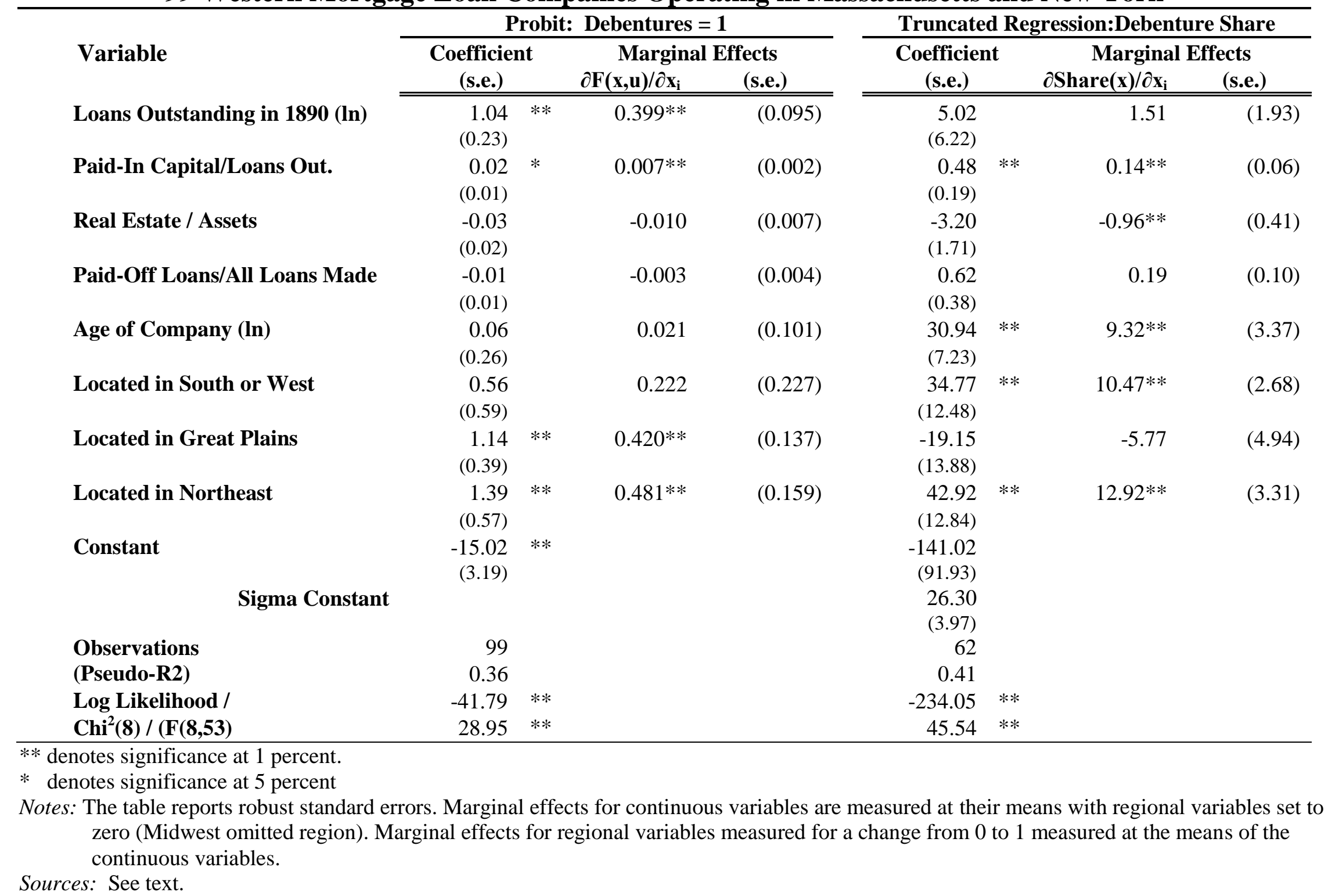




\section{TABLE 4}

689 Mortgages Made In Kansas In 1887:

Watkins' Brokered And Debenture Mortgages

\begin{tabular}{|c|c|c|c|c|}
\hline \multirow[b]{2}{*}{ Number of loans : } & \multicolumn{2}{|c|}{$\begin{array}{c}\text { Brokered Mortgage } \\
\text { Loans }\end{array}$} & \multicolumn{2}{|c|}{$\begin{array}{c}\text { Loans Placed } \\
\text { Behind Debenture }\end{array}$} \\
\hline & 465 & $67.5 \%$ & 224 & $32.5 \%$ \\
\hline \multicolumn{5}{|l|}{ Average (s.d.): } \\
\hline Amount of loan (\$) & $\$ 628$ & $(355)$ & $\$ 536$ & ( 303 \\
\hline Size of farm (acres) & 145 & $(48)$ & 148 & $(32)$ \\
\hline Debt per acre & $\$ 4.51$ & $(2.20)$ & $\$ 3.76$ & ( 2.07 \\
\hline Miles from Watkins & 245 & $(56)$ & 287 & $(66)$ \\
\hline \multicolumn{5}{|l|}{ Number of Loans: } \\
\hline Less than 5 years & 31 & $6.7 \%$ & 67 & $29.9 \%$ \\
\hline Small loan (amount < \$400) & 77 & $16.6 \%$ & 63 & $28.1 \%$ \\
\hline Large loan (amount > \$700) & 100 & $21.5 \%$ & 22 & $9.8 \%$ \\
\hline Western Kansas & 49 & $10.5 \%$ & 84 & $37.5 \%$ \\
\hline Quarter I & 184 & $39.6 \%$ & 59 & $26.3 \%$ \\
\hline Quarter II & 118 & $25.4 \%$ & 14 & $6.3 \%$ \\
\hline Quarter III & 104 & $22.4 \%$ & 45 & $20.1 \%$ \\
\hline Quarter IV & 59 & $12.7 \%$ & 106 & $47.3 \%$ \\
\hline \multicolumn{5}{|l|}{ Average (s.d.): } \\
\hline $\begin{array}{l}\text { Effective annual interest rate } \\
\text { Gross rate of return }\end{array}$ & $10.09 \%$ & (1.10) & $10.77 \%$ & $(1.36)$ \\
\hline $\begin{array}{l}\text { Under contract to: } \\
\text { Loan Agents }\end{array}$ & $0.55 \%$ & $(0.26)$ & $0.71 \%$ & $(0.33)$ \\
\hline Watkins & $3.07 \%$ & $(1.00)$ & $4.05 \%$ & (1.17) \\
\hline Investors & $6.12 \%$ & $(0.33)$ & $5.54 \%$ & $(0.50)$ \\
\hline
\end{tabular}

Sources: The number, amount and all lending terms for mortgages marketed by the Watkins Company were drawn directly from the company's original mortgage ledgers. 
TABLE 5

Mortgage Rates and Foreclosure : 689 Kansas Loans

\begin{tabular}{|c|c|c|c|c|c|c|c|}
\hline \multirow[b]{2}{*}{ Variable } & \multicolumn{3}{|c|}{$\begin{array}{c}\text { Effective } \\
\text { Mortgage Rate }\end{array}$} & \multicolumn{4}{|c|}{$\begin{array}{c}\text { Probit Model } \\
\text { of Foreclosure }\end{array}$} \\
\hline & \multicolumn{2}{|c|}{$\begin{array}{c}n=689 \\
\text { Coefficient }\end{array}$} & \multirow{2}{*}{$\frac{\text { [s.e.] }^{\text {a }}}{(0.24)}$} & \multicolumn{2}{|c|}{$\begin{array}{c}n=689 \\
\text { Coefficient }\end{array}$} & \multirow{2}{*}{$\frac{[\text { [s.e.. }]^{\mathrm{a}}}{(0.68)}$} & \multirow{2}{*}{$\begin{array}{c}\begin{array}{c}\text { Marginal } \\
\text { Effects }^{\mathbf{b}}\end{array} \\
0.74\end{array}$} \\
\hline Constant & 8.34 & $* *$ & & -3.32 & $* *$ & & \\
\hline Debenture Loan & 0.01 & & $(0.06)$ & -0.23 & & $(0.14)$ & -0.08 \\
\hline \multicolumn{8}{|l|}{ Loan Characteristics } \\
\hline Large Amount & -0.20 & $* *$ & $(0.07)$ & 0.00 & & $(0.18)$ & 0.00 \\
\hline Small Amount & 0.03 & & $(0.07)$ & -0.34 & * & $(0.17)$ & -0.13 \\
\hline Short Maturity & 0.39 & $* *$ & $(0.09)$ & -0.34 & & $(0.18)$ & -0.13 \\
\hline Debt/Acre $(\ln )$ & -0.06 & & $(0.09)$ & 1.18 & $* *$ & $(0.22)$ & 0.43 \\
\hline \multicolumn{8}{|l|}{ Location Measures } \\
\hline Miles from Watkins $(\ln )$ & 2.34 & $* *$ & $(0.18)$ & 2.65 & $* *$ & $(0.58)$ & 0.96 \\
\hline Western Kansas & 0.54 & $* *$ & $(0.09)$ & -0.17 & & $(0.24)$ & -0.06 \\
\hline Newly Settled & 0.48 & $* *$ & $(0.08)$ & 1.19 & $* *$ & $(0.29)$ & 0.37 \\
\hline \multicolumn{8}{|l|}{ Market Conditions } \\
\hline Watkins's Loans $(\$ 000)$ & -0.36 & $* *$ & $(0.06)$ & -0.45 & * & $(0.21)$ & -0.16 \\
\hline Watkins's Foreclosure & 0.08 & & $(0.07)$ & 0.02 & & $(0.15)$ & 0.01 \\
\hline Loan by Big Agent & 0.10 & & $(0.06)$ & 0.05 & & $(0.13)$ & 0.02 \\
\hline Made in Quarter II & -0.31 & $* *$ & $(0.07)$ & 0.20 & & $(0.16)$ & 0.07 \\
\hline Made in Quarter III & -0.63 & $* *$ & $(0.07)$ & -0.08 & & $(0.16)$ & -0.03 \\
\hline Made in Quarter IV & -0.57 & $* *$ & $(0.07)$ & -0.15 & & $(0.15)$ & 0.01 \\
\hline \multicolumn{8}{|l|}{ Post-1887 Conditions } \\
\hline$\%$ Ch-Debt/Acre:1887-89 & & & & -0.61 & $* *$ & $(0.23)$ & -0.22 \\
\hline$\%$ Ch-Acr in Debt 1887-89 & & & & -0.02 & & $(0.54)$ & -0.01 \\
\hline $\mathbf{R}^{2}$ - Pseudo $\mathbf{R}^{2}$ & 0.74 & & & 0.238 & & & \\
\hline Log Likelihood & & & & -343.9 & & & \\
\hline$(\mathbf{F}(\mathbf{1 4}, \mathbf{6 7 4}) /$ & $156.8 * *$ & & & & & & \\
\hline Chi2(13/9) & & & & & & & \\
\hline
\end{tabular}

** denotes significance at 1 percent.

* denotes significance at 5 percent

Notes: The table reports robust standard errors. Marginal effects for continuous variables are measured at their means with dummy variables set to zero. Marginal effects for dummy variables for a change from 0 to 1 at the means of the continuous variables.

Sources: See the text. 
TABLE 6

Debenture Status: 689 Kansas Loans

Probit: Debenture =

$(n=689)$

Full Information

Variable

\section{Constant}

\section{Loan Characteristics}

Large Amount

Small Amount

Short Maturity

Debt/Acre (ln)

\section{Location Measures}

Miles from Watkins (ln)

Western Kansas

Newly Settled

\section{Market Conditions}

Watkins's Loans (\$000)

0.18

(0.20)

Watkins's Foreclosure

0.21

(0.16)

Loan by Big Agent

Made in Quarter II

Made in Quarter III

Made in Quarter IV

$\mathbf{R}^{2}$ - Pseudo $\mathbf{R}^{2}$

Log Likelihood

(F(14,674)/Chi ${ }^{2}(13 / 9)$
$-0.40 *$

(0.19)

$0.52 * *$

(0.17)

$1.06 * *$

(0.17)

$0.72 * *$

(0.22)
$(0.49)$

0.40

(0.20)

0.19

(0.18)

$-0.12$

(0.13)

$-0.78 * *$

$(0.18)$

$-0.01$

(0.16)

$0.89 * *$

$(0.15)$

0.26

$-323.20$

$181.10 * *$

$-0.77 * *$

$-0.22 * *$

(0.18)

(0.04)

0.02

0.01

$(0.15)$

$(0.05)$

0.92

$0.34 * *$

$(0.15)$

$(0.05)$

0.25

$-324.70$

** denotes significance at 1 percent.

* denotes significance at 5 percent

Notes: The table reports robust standard errors. Marginal effects for continuous variables are measured at their means with dummy variables set to zero. Marginal effects for dummy variables for a change from 0 to 1 at the means of the continuous variables.

Sources: See the text. 
TABLE 7

Sources of Differences in Mortgage Rates and Gross Returns for Debenture and Brokered Loans

(Predicted Differences Based on Hedonic Models for 689 Kansas Loans) $^{\text {a }}$

\begin{tabular}{|c|c|c|c|c|}
\hline \multirow{3}{*}{ Variable } & \multicolumn{4}{|c|}{ Difference Between Avg. Debenture and Brokered Loan ${ }^{\text {b: }}$} \\
\hline & \multirow{2}{*}{$\begin{array}{l}\text { Effective } \\
\text { Mortgage } \\
\text { Rate }\end{array}$} & \multicolumn{3}{|c|}{ Gross Rate of Return under Contract to: } \\
\hline & & $\begin{array}{c}\text { Loan } \\
\text { Agents }\end{array}$ & Watkins & Investors \\
\hline $\begin{array}{l}\text { Actual Difference in Average } \\
\text { (Debenture Loan-Brokered Loans) }\end{array}$ & 0.68 & 0.16 & 0.98 & -0.58 \\
\hline \multicolumn{5}{|l|}{ Predicted Difference Due To ${ }^{c}$ : } \\
\hline Differences in Average Loan Terms & $0.13 * *$ & $0.07 * *$ & $0.06 *$ & 0.00 \\
\hline $\begin{array}{l}\text { Differences in Average Measures of } \\
\text { Location }\end{array}$ & $0.63 * *$ & $0.13 * *$ & $0.42 * *$ & -0.02 \\
\hline $\begin{array}{l}\text { Differences in Average Market } \\
\text { Conditions }\end{array}$ & $-0.09 * *$ & $-0.01 * *$ & $-0.04 * *$ & $-0.03 * *$ \\
\hline Debenture Status & 0.01 & -0.03 & $0.54 * *$ & $-0.53 * *$ \\
\hline \multicolumn{5}{|c|}{$\begin{array}{l}\text { ** denotes significance at } 1 \text { percent. } \\
\text { * denotes significance at } 5 \text { percent } \\
\text { Notes: The table reports the differences in predicted effects for the average debenture and the average brokered loans using the regression } \\
\text { estimates reported in Appendix Table } 1 . \text { The table reports the sum of the predicted effects for all variables within each group and the stars } \\
\text { report tests of significance for these groups of variables. } \\
\text { Sources: Calculated from regressions reported in Appendix Table } 1 .\end{array}$} \\
\hline
\end{tabular}


APPENDIX TABLE 1

Mortgage Rates and Gross Contract Returns to Agents, Watkins and Investors (n=689)

\begin{tabular}{|c|c|c|c|c|c|c|c|c|}
\hline \multirow[b]{2}{*}{ Constant } & \multicolumn{2}{|c|}{$\begin{array}{c}\text { Effective } \\
\text { Mortgage Rt. } \\
\text { [s.e.] }\end{array}$} & \multicolumn{2}{|c|}{$\begin{array}{c}\text { Agent's } \\
\text { Return } \\
\text { [s.e.] } \\
\end{array}$} & \multicolumn{2}{|c|}{$\begin{array}{c}\text { Watkins's } \\
\text { Return } \\
\text { [s.e.] } \\
\end{array}$} & \multicolumn{2}{|c|}{$\begin{array}{c}\text { Investors' } \\
\text { Return } \\
\text { [s.e.] }\end{array}$} \\
\hline & $\begin{array}{r}8.34 \\
(0.24)\end{array}$ & $* *$ & $\begin{array}{r}0.17 \\
(0.06)\end{array}$ & $* *$ & $\begin{array}{r}1.68 \\
(0.31)\end{array}$ & $* *$ & $\begin{array}{r}6.36 \\
(0.15)\end{array}$ & $* *$ \\
\hline Debenture Loan & $\begin{array}{r}0.01 \\
(0.06)\end{array}$ & & $\begin{array}{l}-0.03 \\
(0.02)\end{array}$ & & $\begin{array}{r}0.54 \\
(0.07)\end{array}$ & $* *$ & $\begin{array}{l}-0.53 \\
(0.04)\end{array}$ & $* *$ \\
\hline $\begin{array}{c}\text { Loan Characteristics } \\
\text { Large Amount }\end{array}$ & $\begin{array}{r}-0.20 \\
(0.07)\end{array}$ & $* *$ & $\begin{array}{r}-0.04 \\
(0.02)\end{array}$ & $* *$ & $\begin{array}{l}-0.05 \\
(0.09)\end{array}$ & & $\begin{array}{r}-0.03 \\
(0.05)\end{array}$ & \\
\hline Small Amount & $\begin{array}{r}0.03 \\
(0.07)\end{array}$ & & $\begin{array}{r}0.01 \\
(0.02)\end{array}$ & & $\begin{array}{r}0.12 \\
(0.09)\end{array}$ & & $\begin{array}{l}-0.10 \\
(0.05)\end{array}$ & $*$ \\
\hline Short Maturity & $\begin{array}{r}0.39 \\
(0.09)\end{array}$ & $* *$ & $\begin{array}{r}0.26 \\
(0.04)\end{array}$ & $* *$ & $\begin{array}{r}0.14 \\
(0.09)\end{array}$ & & $\begin{array}{r}0.03 \\
(0.05)\end{array}$ & \\
\hline Debt/Acre (ln) & $\begin{array}{r}-0.06 \\
(0.09)\end{array}$ & & $\begin{array}{r}0.00 \\
(0.02)\end{array}$ & & $\begin{array}{l}-0.05 \\
(0.10)\end{array}$ & & $\begin{array}{l}-0.04 \\
(0.05)\end{array}$ & \\
\hline \multicolumn{9}{|l|}{ Location Measures } \\
\hline Miles from Watkins (ln) & $\begin{array}{r}2.34 \\
(0.18)\end{array}$ & $* *$ & $\begin{array}{r}0.42 \\
(0.05)\end{array}$ & $* *$ & $\begin{array}{r}1.86 \\
(0.23)\end{array}$ & $* *$ & $\begin{array}{l}-0.10 \\
(0.11)\end{array}$ & \\
\hline Western Kansas & $\begin{array}{r}0.54 \\
(0.09)\end{array}$ & $* *$ & $\begin{array}{r}0.18 \\
(0.03)\end{array}$ & $* *$ & $\begin{array}{l}0.06 \\
0.10\end{array}$ & & $\begin{array}{r}0.03 \\
(0.05)\end{array}$ & \\
\hline Newly Settled & $\begin{array}{r}0.47 \\
(0.08)\end{array}$ & $* *$ & $\begin{array}{r}0.05 \\
(0.02)\end{array}$ & $*$ & $\begin{array}{r}0.44 \\
(0.09)\end{array}$ & $* *$ & $\begin{array}{l}-0.06 \\
(0.04)\end{array}$ & \\
\hline \multicolumn{9}{|l|}{ Market Conditions } \\
\hline Watkins's Loans (\$000) & $\begin{array}{r}-0.36 \\
(0.06)\end{array}$ & $* *$ & $\begin{array}{l}-0.09 \\
(0.02)\end{array}$ & $* *$ & $\begin{array}{l}-0.27 \\
(0.09)\end{array}$ & $* *$ & $\begin{array}{r}0.03 \\
(0.05)\end{array}$ & \\
\hline Watkins's Foreclosure & $\begin{array}{r}0.08 \\
(0.07)\end{array}$ & & $\begin{array}{r}0.01 \\
(0.02)\end{array}$ & & $\begin{array}{l}-0.02 \\
(0.08)\end{array}$ & & $\begin{array}{r}0.04 \\
(0.04)\end{array}$ & \\
\hline Loan by Big Agent & $\begin{array}{r}0.10 \\
(0.06)\end{array}$ & & $\begin{array}{r}0.08 \\
(0.02)\end{array}$ & $* *$ & $\begin{array}{l}-0.08 \\
(0.06)\end{array}$ & & $\begin{array}{r}0.02 \\
(0.03)\end{array}$ & \\
\hline Made in Quarter II & $\begin{array}{r}-0.31 \\
(0.07)\end{array}$ & $* *$ & $\begin{array}{l}-0.06 \\
(0.02)\end{array}$ & $* *$ & $\begin{array}{l}-0.05 \\
(0.09)\end{array}$ & & $\begin{array}{l}-0.16 \\
(0.04)\end{array}$ & $* *$ \\
\hline Made in Quarter III & $\begin{array}{r}-0.63 \\
(0.06)\end{array}$ & $* *$ & $\begin{array}{l}-0.07 \\
(0.02)\end{array}$ & $* *$ & $\begin{array}{l}-0.21 \\
(0.07)\end{array}$ & $* *$ & $\begin{array}{r}-0.27 \\
(0.04)\end{array}$ & $* *$ \\
\hline Made in Quarter IV & $\begin{array}{r}-0.56 \\
(0.07)\end{array}$ & $* *$ & $\begin{array}{r}-0.06 \\
(0.02)\end{array}$ & $* *$ & $\begin{array}{r}-0.36 \\
(0.08)\end{array}$ & $* *$ & $\begin{array}{l}-0.15 \\
(0.04)\end{array}$ & $* *$ \\
\hline$\left(\mathbf{R}^{2}\right)$ & 0.74 & & 0.62 & & 0.58 & & 0.40 & \\
\hline$(\mathrm{F}(\mathbf{1 4 / 6 7 4 ) )}$ & 156.80 & & 73.40 & & 73.20 & & 23.6 & \\
\hline
\end{tabular}

** denotes significance at 1 percent.

* denotes significance at 5 percent

Notes: The table reports robust standard errors.

Sources: See the text. 